Research, part of a Special Feature on Why does hunting in tropical regions matter?

\title{
Ride, shoot, and call: wildlife use among contemporary urban hunters in Três Fronteiras, Brazilian Amazon
}

\author{
$\underline{\text { Nathalie van Vliet }}^{1}, \underline{\text { Daniel Cruz }}^{2}, \underline{\text { Maria Paula Quiceno-Mesa }}^{3}, \underline{\text { Lindon Jonhson Neves de Aquino }}^{4}$, Jessica Moreno $^{3}, \underline{\text { Rairon Ribeiro }}^{5}$ \\ and Julia $\mathrm{Fa}^{\mathrm{I}}$
}

\begin{abstract}
Most bushmeat studies in the Amazon region focus on hunting patterns of indigenous populations in rural settings. Our study describes the existence of urban hunters in medium-sized towns. Using a variety of data collection methods, we describe the main socioeconomic characteristics of urban hunters in Benjamin Constant and Atalaia do Norte, Brazil. We analyze the patterns and motivations of urban hunters as well as the type of prey harvested and quantities traded. All interviewed hunters are caboclos, people of mixed Brazilian indigenous and European origins from rural areas who now live in urban and peri-urban areas. Living in these more populated spaces allows these hunters better market options for their harvest and allows them to alternate hunting with other economic activities. Only $29 \%$ of the interviewed hunters relied solely on hunting. In total, 11.6 tons of bushmeat were harvested (of which $97 \%$ was traded) by four hunters during the monitoring period (60 days). The most hunted species were terecay (Podocnemis unifilis), curassow (Crax sp.), paca (Cuniculus paca), and tapir (Tapirus terrestris). The ratio of bushmeat sold to that consumed, as well as the level of participation in the bushmeat market chain, allowed us to differentiate between specialized and diversified hunters. Specialized hunters sell $81 \%$ of the bushmeat caught to known wholesalers in the city. Diversified hunters sell $21 \%$ of their total catch to families, neighbors, or friends directly as fresh meat, avoiding intermediaries. For all hunters, hunting localities are associated with peri-urban roadways that are easily reached by motorbike or bicycle from the hunters' houses in the urban areas or city fringes. Our results show that urban hunters in medium-sized towns exemplify how traditional hunting systems can be adapted in the face of globalization, by living close to the market, at relatively manageable distances from hunting grounds, and using modern methods of transportation and communication to bypass law enforcement.
\end{abstract}

Key Words: Brazil; bushmeat; hunting; subsistence hunting; Três Fronteiras; urban hunters

\section{INTRODUCTION}

Although rapid social and economic transformations have caused a loss in the importance of forest products in rural people's nutrition and livelihoods in the Amazon (Sills et al. 2011), bushmeat continues to play an important role in the subsistence of these communities (Ojasti 2000, Bodmer and Lozano 2001, Bodmer et al. 2004, Nasi et al. 2011). Most of the Amazon Basin's forests are inhabited by indigenous people (Schwartzman et al. 2000 , Nepstad et al. 2006) who rapidly join the global marketplace and are able to acquire modern weapons and tools (guns, steel tools, fishing gear, chainsaws) and motorized transport. As a result, scientific research on bushmeat in the Amazon has focused on assessing hunting practices and their effects on biodiversity conservation (Ayres and Ayres 1979, Bodmer et al. 1997, EmídioSilva 1998, Lopes and Ferrari 2000, Peres 2001, Zapata-Ríos 2001, Bodmer et al. 2004, Bonaudo et al. 2005, da Silva et al. 2005, Levi et al. 2009, Parry et al. 2009, Prado et al. 2012, Shepard et al. 2012). There has been a limited number of studies dealing with the economics and social underpinnings of Amazonian hunting (Read et al. 2010, Iwamura et al. 2014). This contrasts with studies in Africa, where interdisciplinary approaches have been used to understand better the demand for and trade of wild meat (Barlow et al. 2011).

Most bushmeat studies undertaken in the Amazon region have focused on hunting by indigenous populations in rural settings (Hurtado-Gonzalez and Bodmer 2004, Gavin 2007, Zapata-Ríos et al. 2009, Shepard et al. 2012, Iwamura et al. 2014). However, because indigenous and traditional communities in the Amazon are currently changing dramatically due to globalization and urbanization, they are becoming increasingly connected to global markets, and people are forced to diversify their income when they move to urban centers (Steward 2007). This weakens people's ability to sustain traditional resource management practices and changes their collective political organization (Brondizio et al. 2009). Indeed, demographic changes and market integration resulting from a move to urban areas can lead to adaptation and even a breakdown of traditional resource management systems (Adams et al. 2013). The Amazon region is progressively influenced by immigration of people, including rural-urban movement of indigenous people, who are attracted by flourishing urban economies based on government subsidies, wood extraction, drug trafficking, wildlife trade, fisheries, and agricultural production (Padoch et al. 2008, Parry et al. 2010). Migration patterns are not uni-directional, but are characterized by complex fluxes of people that result in great mobility of multilocated and multi-ethnic households affected by job availability, flooding patterns, violent displacement, and extractive booms (Alexiades 2009, Eloy and Le Tourneau 2009, Adams et al. 2013, Nasuti et al. 2013). These demographic changes lead to new urban-rural interconnections that translate into complex social networks of interchange (Nasutiet al. 2013) and have implications in the ways that urban people connect and use the forest and, more particularly, use the wildlife.

In fact, small and medium-sized towns in the Amazon have given rise to peri-urban hunters, but their practices, motivations, and contributions to the urban bushmeat trade remain little studied. Here, we use a combination of participatory methods, including participatory mapping, participant observation, semi-structured

${ }^{1}$ Center for International Forestry Research, ${ }^{2}$ Fundación Science International - CIFOR, ${ }^{3}$ Fundación Science International, ${ }^{4}$ Universidade Federal do Amazonas, ${ }^{5}$ Universidade Federal do Amazonas, Instituto Natureza e Cultura 
Fig. 1. Map of the study area.

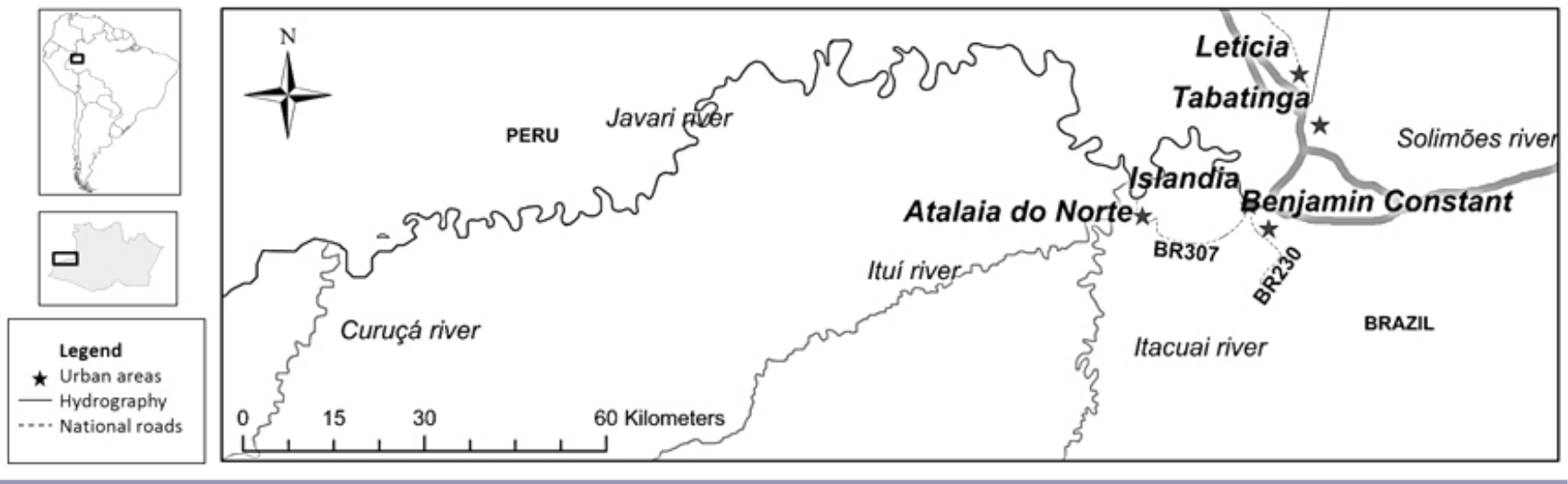

interviews, and participatory monitoring, to describe the roles that peri-urban hunters play in current hunting practices in the Amazon. We undertook our research in two towns within the Três Fronteiras (Trifrontier) region in Brazil: Benjamin Constant and Atalaia do Norte. We investigated who these peri-urban hunters are (i.e., their origins, ethnic groups, socioeconomic backgrounds, and motivations for hunting), their hunting practices, their legitimacy in terms of resource-use rights within their hunting grounds, and their contribution to urban bushmeat markets.

\section{METHODS}

\section{Study site}

The study was carried out in 2012-2013 in two towns within Três Fronteiras, Brazil (Fig. 1): Benjamin Constant (37,564 inhabitants) and Atalaia do Norte (17,174 inhabitants; IBGE 2013). The study area is characterized by an equatorial tropical climate, a unimodal-biseasonal rainfall regime (dry/semi-dry seasonality with a multi-annual average precipitation of 2500 $3600 \mathrm{~mm}$ ), and an average temperature of $25.7^{\circ} \mathrm{C}$ (Coelho et al. 2005, Serrâo Acioli and Cassiano Oliveira 2013). The geography of the area is characterized by the Amazon floodplain and crossed by river plains of the Solimôes, Içá, Purué, and Japurá rivers (Albán Morán et al. 2004). The predominant soils are cambisols and gleysols (Coelho et al. 2005, Serrâo Acioli and Cassiano Oliveira 2013).

The population in the study area is highly ethnically diverse; among the most predominant peoples are the Ticuna, Cocama, Caizana, Marubo, Matiz, Kanamari, Kulina, and Mayoruna. Ticuna is the predominant ethnic group, especially in the Três Fronteiras region (Brazil, Colombia, and Peru), and they populate approximately eight municipalities in the Brazilian state of Amazonas (da Silva 2009). In some municipalities, indigenous groups represent more than one-half of the rural population. The Cocama also live in the tri-border Amazon; in Brazil, they inhabit the Solimôes River, from the city of Anama to Tabatinga, Amazonas (da Silva 2009). The caboclo or Ribeirinho populations are a mix of indigenous groups and Europeans resulting in a fusion culture of institutionalized Catholic Church beliefs, myths, and indigenous cultural heritage (Galvâo 1967). The Benjamin Constant Municipality comprises 50 rural communities: 30 caboclo and 20 indigenous communities (IBGE 2000). The Municipality of Atalaia do Norte has 65 rural communities: 14 caboclo and 51 indigenous communities (Gasparetto Higuchi et al. 2011).

In rural areas, the main economic activities are fishing and agriculture (cassava, maize, rice, beans, fruits, and some vegetables), nontimber forest product extraction (Brazil nut, guarana, açaí, hunting), and logging (Albán Morán et al. 2004, Peiter et al. 2013). Government subsidies (e.g., bolsa familia) now also contribute substantially to local economies. Industrial activity is confined to the soft drinks industry, bakeries, clothing production, and commercial trade (Albán Morán et al. 2004). The primary sector economy in the Municipality of Benjamin Constant is based on forest and wildlife extraction (hunting and fishing), agriculture, and tourism. Agriculture is based on seasonal crops such as cassava, rice, beans, corn, watermelon, banana, cupuaçu, chontaduro, and some citrus fruits (da Silva 2009). Road construction (BR 307) between Atalaia do Norte and Benjamin Constant connected the two towns in the 1980s and allowed major changes in access to hunting grounds and markets.

\section{Data collection}

We used a variety of approaches to describe urban hunters, including participant observation, participatory mapping, semistructured interviews, and participatory monitoring. Given the fact that the urban bushmeat trade is illegal and therefore hidden, we spent 3-4 months in 2012 observing the general market (vegetables, fruits, fish, and meat), engaging with consumers, identifying and approaching traders through informal discussions, and sharing meals, until we identified the channels in which bushmeat is sold and were able to travel to potential source areas to contact the hunters. This time investment was crucial to gain the confidence of hunters and to be introduced to them by the market traders with whom they are in business. We used a snowball technique to identify other urban hunters.

Once we had established the approximate number of urban hunters involved and had developed a collaborative relationship with them, we were able to explain the objectives and approach of our research and include the hunters as active informants. We conducted semi-structured interviews (Appendix 1) to describe the hunters' socioeconomic characteristics, hunting techniques used, frequency of hunting, and motivations for hunting. These 
Fig. 2. Map showing the origins of urban hunters from Benjamin Constant and Atalaia do Norte, Brazil.

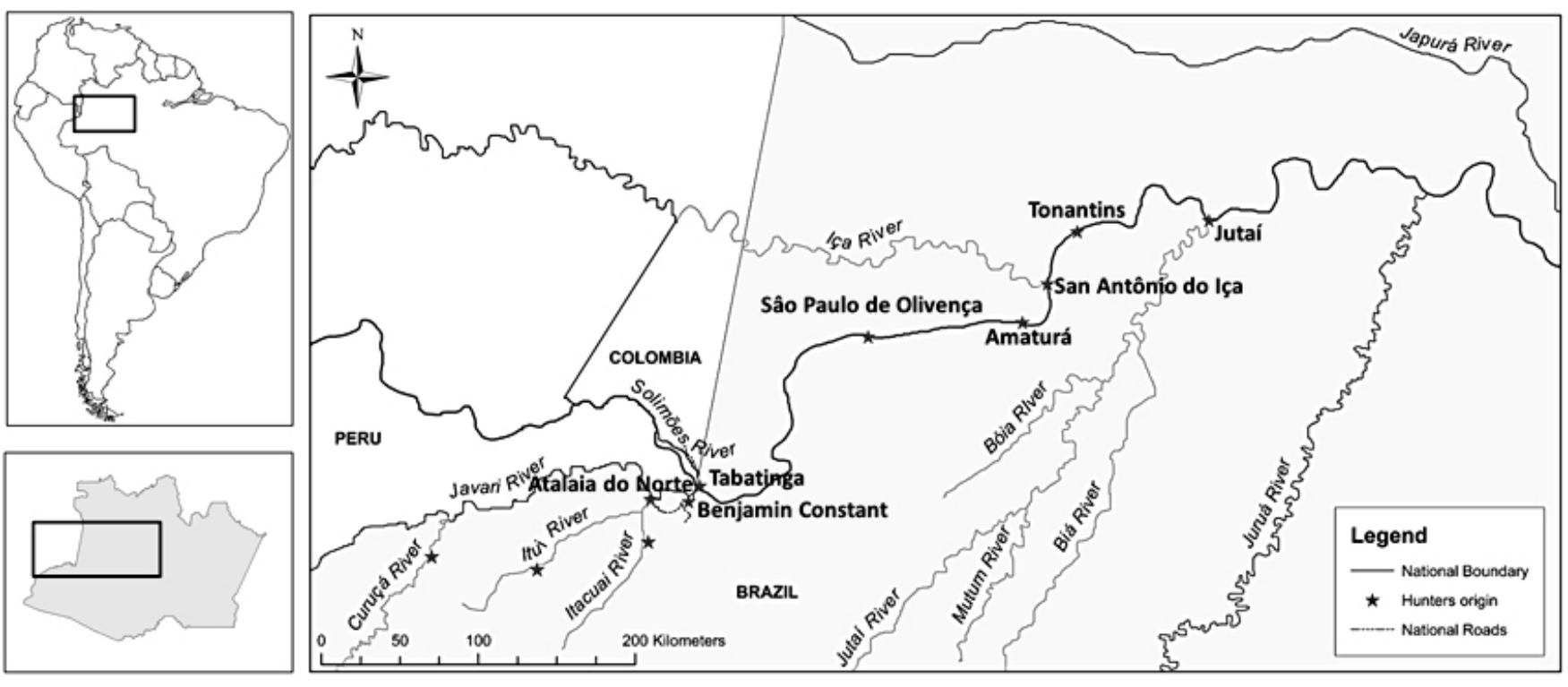

interviews were carried out during visits to peri-urban and urban neighborhoods. Interviews were coupled with a participatory mapping exercise (Appendix 2) to locate the most commonly used hunting grounds and landscape features (e.g., trails, rivers, and hunting camps) used during hunting. A total of 31 interviews were conducted $(72 \%)$ out of the 43 urban hunters identified as participating in the bushmeat market chain in Benjamin Constant and Atalaia do Norte.

To estimate the amount of total bushmeat hunted and traded by urban hunters, we developed a participatory monitoring approach in which urban hunters $(N=4$ of 43 identified) were responsible for data collection (see Table 1 for sampling effort). Hunters were chosen according to their level of willingness and trust shown by them toward our project during the interview phase, and so that there was a representative sample of hunters from the two study towns. We designed a monitoring notebook for participating hunters to record information on the hunting area used, prey hunted, bushmeat use patterns (for sale or family consumption), costs related to hunting, incentives, seasonality, main customers, prices, type of bushmeat (fresh, salted, smoked), law enforcement, and quantity sold. The monitoring period covered two hydro-climatic phases: one month in May and one month in September 2013 (high and low waters, respectively; 60 days in total). To ensure the quality of self-reported data, we visited the hunters every five days during the monitoring period. Our method may have suffered from self-selection bias because only hunters who were willing to maintain a hunting diary participated in the project.

Finally, from August 2012 to September 2013, we undertook direct observations to triangulate the data recorded. Frequent informal visits to urban hunters were carried out to note the species hunted, prices, and quantities, and to conduct informal conversations with the hunters to collect qualitative information about their activities.
Table 1. Total numbers of urban hunters and numbers of hunters sampled in two cities in Brazil.

\begin{tabular}{llccc}
\hline \hline Country & City & $\begin{array}{c}\text { Hunters } \\
\text { interviewed }\end{array}$ & $\begin{array}{c}\text { Hunters } \\
\text { participating } \\
\text { in } \\
\text { monitoring }\end{array}$ & $\begin{array}{c}\text { Total } \\
\text { hunters } \\
\text { identified }\end{array}$ \\
\hline Brazil & Benjamin Constant & 24 & 2 & 31 \\
& Atalaia do Norte & 7 & 2 & 12 \\
Total & & $31(72 \%)$ & $4(9 \%)$ & 43 \\
\hline
\end{tabular}

\section{RESULTS}

Socioeconomic characteristics of the hunters

All hunters interviewed were caboclos. Hunters were an average of 42 years old, most $(82 \%)$ were married or cohabited, and the mean household size of hunters was 4.5 people. Most hunters lived in basic homesteads built of wood with zinc roof tiles. Most of the interviewed hunters $(80 \%)$ had migrated from other regions of the Brazilian Amazonas State to the Trifrontier region from settlements along the Ataquaí, Curuçá, and Ituí rivers, and from the towns of Amatura, Jutaí, Tonantins, São Jose, São Paulo de Olivença, and the capital city of Manaus (Fig. 2), motivated by the 1960 s boom in the rubber, logging, and pelt industries. Living in the cities or peri-urban areas allows the hunters to access better market options for their harvests and to alternate hunting with other economic activities such as security guarding, transportation, carpentry, farm caretaking, and laboring in construction, which are often based on a daily wage. Most interviewed hunters sold their products of agriculture, fishing, and timber extraction as their main alternative activities (42\%); only $29 \%(N=9)$ relied on hunting as their main source of income. 
Species, biomass harvested, and contribution to urban bushmeat trade

A total of 11.6 tons of bushmeat were hunted by the four hunters interviewed during a 60 -day monitoring period: 4.1 tons in the high-water season, and 7.4 tons during the low-water season. Most $(97 \%)$ of the prey species hunted were sold in the marketplace of each town. The most hunted species (340 individuals) were terecay (Podocnemis unifilis, 18\%), curassow (Crax sp., 13\%), paca (Cuniculus paca, 13\%), and tapir (Tapirus terrestris, 12\%; Fig. 3).

Fig. 3. Species and numbers of individuals hunted during the two monitoring periods (low- and high-water seasons) by four urban hunters.

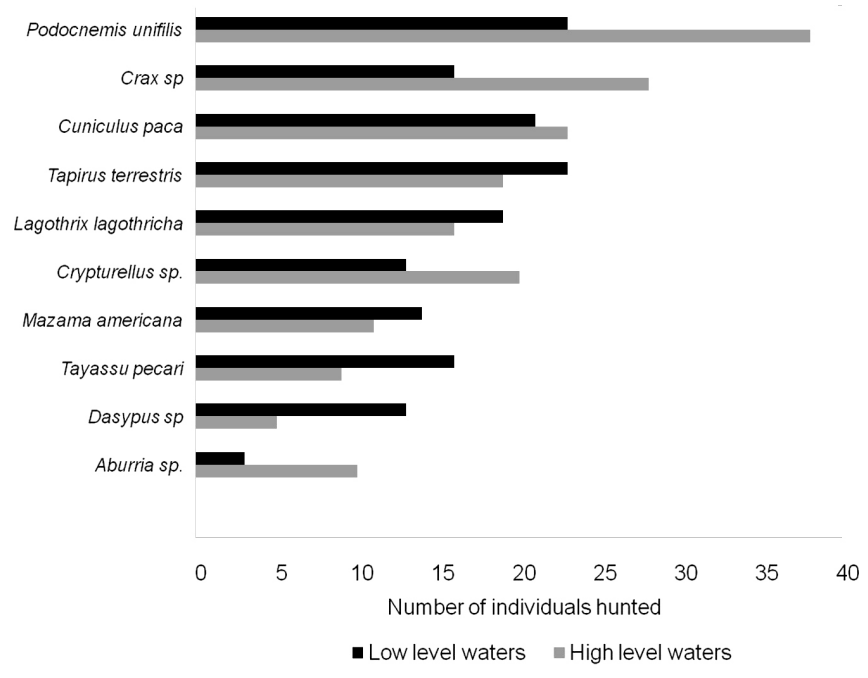

For a given hunter, if the ratio of bushmeat sold to bushmeat consumed was greater than one-third, and hunting was acknowledged as one of the three most important livelihood activities, then that hunter was classified as a specialized hunter. Specialized hunters sold $81 \%$ of bushmeat caught to regular clients in the city (families, teachers, public employees, traders) or to wholesalers who requested wild meat in advance by mobile phone. An average of 15 clients were registered per hunter, of which a mean of 4 were long-term clients. Bushmeat was sold either fresh, smoked, alive, or salted: turtles were sold alive; birds, paca, and medium-sized mammals such as rodents and armadillos were sold fresh; and tapirs and peccaries were sold smoked or salted. Diversified hunters based their activity on subsistence hunting, selling an average $21 \%$ of their total catch to families, neighbors, and friends at their houses or via mobile phone calls. These hunters avoided selling bushmeat in marketplaces because of legal controls. Most bushmeat traded by these hunters was sold fresh, directly to the final consumers, thus avoiding intermediaries.

\section{Hunting practices}

Hunters used shotguns and traps: $65 \%$ used shotguns exclusively, $26 \%$ used both shotguns and traps, and $6 \%$ used a combination of traps and dogs (Table 2). Hunting with dogs is not frequently practiced because they tend to chase animals away. The costs of purchasing legal shotguns are high (USD \$760, plus legal procedures), which often encourages hunters to buy guns in the illegal market for better prices (USD \$255-400). Traps are mostly handmade and consist of placing an automatic handmade shotgun made of steel or wood that shoots when an animal comes across a steel strip. Traps are placed on wildlife trails overnight from $5 \mathrm{pm}$ to $5 \mathrm{am}$ (due to the risk of harming other hunters or people passing). A maximum of eight traps per hunter are usually set simultaneously in the hunting territory. Other commonly used traps are the arapuca, a wooden pyramidal trap that traps the animal when it tries to take bait hung on a stick inside the structure, which are designed to catch terrestrial birds and small mammals. Differences in the frequency of hunting, supplies used, effort, and success show that specialized hunters spend more days hunting and buy more cartridges, which results in twice the number of prey caught compared to that obtained by diversified hunters (Table 3 ).

Table 2. Differences in hunting tools used by specialized and diversified hunters.

\begin{tabular}{lccc}
\hline \hline Type of hunter & \multicolumn{3}{c}{ Hunting tools used (\% of hunters) } \\
\cline { 2 - 4 } & $\begin{array}{c}\text { Shotgun } \\
\text { only }\end{array}$ & $\begin{array}{c}\text { Shotgun } \\
\text { and dogs }\end{array}$ & $\begin{array}{c}\text { Shotgun } \\
\text { and traps }\end{array}$ \\
\hline Diversified hunters & 79 & 15 & 10 \\
Specialized hunters & 56 & 0 & 30 \\
\hline
\end{tabular}

Table 3. Differences in hunting practices and patterns of specialized and diversified hunters.

\begin{tabular}{lccccc}
\hline \hline $\begin{array}{l}\text { Type of } \\
\text { hunter }\end{array}$ & $\begin{array}{c}\text { Cartridges } \\
\text { per } \\
\text { hunting } \\
\text { trip }\end{array}$ & $\begin{array}{c}\text { Prey } \\
\text { caught } \\
\text { per } \\
\text { hunting } \\
\text { trip }\end{array}$ & $\begin{array}{c}\text { Hunting } \\
\text { trips per } \\
\text { month }\end{array}$ & $\begin{array}{c}\text { Days per } \\
\text { hunting } \\
\text { trip }\end{array}$ & $\begin{array}{c}\text { Cartridges } \\
\text { purchased } \\
\text { per } \\
\text { month }\end{array}$ \\
\hline $\begin{array}{l}\text { Diversified } \\
\text { hunters } \\
\begin{array}{l}\text { Specialized } \\
\text { hunters }\end{array}\end{array}$ & $8 \dagger$ & 3.8 & 2.6 & 3.4 & 31 \\
\hline
\end{tabular}

$\dagger$ †ll numbers are means.

Hunters have developed an array of techniques to find and capture animals, which involve seeking prey at night and in the early morning, preferably at the new moon. Hunters look for animal tracks and either wait patiently for the animal to cross or follow the trail until they encounter the animal. Another technique is to build a platform (from sticks and branches) over a salt-lick point, where the hunter waits for approximately $5 \mathrm{~h}$ for animals to arrive. Hunters also walk along the borders of streams at night looking for animals drinking water. When an animal is found, the hunter dazzles the prey with a lantern and shoots it immediately. Opportunistic hunting is associated with fishing in flooded forests, lakes, and streams, where birds, monkeys, and turtles can be found; hunters take their shotguns with them in case any prey is observed.

Based on traditional knowledge, hunters know how prey availability fluctuates: $54 \%$ of the interviewed hunters explained that during the high-water season (November to June) capturing 
Table 4. Species most commonly hunted and habitat type where they are usually found.

\begin{tabular}{|c|c|c|c|c|c|}
\hline Species & Primary forest & $\begin{array}{c}\text { Riparian forest and } \\
\text { streams }\end{array}$ & Secondary forest & Transformed habitats & River sand beaches \\
\hline Dasypus sp. & $\mathrm{X}$ & $\mathrm{X}$ & $\mathrm{X}$ & $\mathrm{X}$ & \\
\hline Cuniculus paca & $\mathrm{X}$ & $\mathrm{X}$ & $\mathrm{X}$ & $\mathrm{X}$ & \\
\hline Crypturellus sp., Tinamus sp. & $\mathrm{X}$ & $\mathrm{X}$ & $\mathrm{X}$ & $X$ & \\
\hline Dasyprocta fuliginosa & $\mathrm{X}$ & $\mathrm{X}$ & & $\mathrm{X}$ & \\
\hline Crax mitu & $\mathrm{X}$ & $\mathrm{X}$ & $\mathrm{X}$ & & \\
\hline Mazama gouazoubira & $\mathrm{X}$ & $\mathrm{X}$ & $\mathrm{X}$ & & \\
\hline Mazama americana & $\mathrm{X}$ & $\mathrm{X}$ & $\mathrm{X}$ & & \\
\hline Didelphis marsupialis & & & $\mathrm{X}$ & $\mathrm{X}$ & \\
\hline Tapirus terrestris & $\mathrm{X}$ & $X$ & & & \\
\hline Pecari tajacu & $\mathrm{X}$ & $\mathrm{X}$ & & & \\
\hline Tayassu pecari & $\mathrm{X}$ & $\mathrm{X}$ & & & \\
\hline Hydrochoerus hydrochaeris & $\mathrm{X}$ & $\mathrm{X}$ & & & \\
\hline Penelope јасqиаси & $\mathrm{X}$ & & $\mathrm{X}$ & & \\
\hline Podocnemis unifilis & & & & & $\mathrm{X}$ \\
\hline Psophia sp. & $\mathrm{X}$ & & & & \\
\hline Lagothrix lagothricha & $\mathrm{X}$ & & & & \\
\hline Coendou prehensilis, C. bicolor & $\mathrm{X}$ & & & & \\
\hline Chelonoidis denticulata & & & $\mathrm{X}$ & & \\
\hline
\end{tabular}

animals is easier because there is better access to headwaters, palms such as açaí are fruiting, and animals become restricted to highlands. In addition, the soil is wet and allows for spotting tracks and trails easily. During the dry season (July to October), as a result of water scarcity, animals are easier to find at salt-lick points and stream borders. Animals associated with crops are constant throughout the year. The chances of finding a wildlife species vary depending on the type of vegetation. Cuniculus paca, Dasyprocta fuliginosa, Dasypus sp., and Crypturellus sp. are found in transformed habitats and are also attracted by crops. Tapirus terrestris, Tayassu pecari, and Pecari tajacu are found mainly in primary and riparian forests (Table 4).

\section{Hunting grounds}

Hunting areas were associated with peri-urban roads (BR307 and BR 230 in Benjamin Constant, Atalaia do Norte, and Crajarí) that are easily reached by motorcycle or bicycle from the hunters' houses in the urban area or city fringes. Hunting grounds along the roads are located in agro-extractivist settlements designated as such by the National Institute of Colonization and Agrarian Reform (INCRA), in which subsistence agricultural activities and hunting for own consumption are allowed. Most hunters have relatives or friends that own homesteads in the fringes of these reserves and allow them to hunt frequently (Appendix 2). The roadways work as a backbone from where most hunters start their approach by foot, with a duration of $1-8 \mathrm{~h}$ to reach the main prey zone. Wildlife can be caught throughout the hunting trails, as a gradient of vegetation cover goes from managed habitats (agricultural fields [roças], fallows [capoeiras], forest fragments [matos] and home gardens [quitais]) to flooded forests (associated with riparian vegetation along streams, lakes, and rivers) and primary forests (Tierra firme, floresta fechada). The most preferred habitats are primary forests (46\% in interviews) and streams (26\% in interviews). Hunting places are chosen depending on the abundance of fruit trees or palms as well as the number of streams and salt licks found. Hunters reported an average of eight salt licks per hunting place. Diversified hunters alternate individual hunting with group hunting (53\% of hunting trips organized by diversified hunters were group hunts), but individual hunting was most common when searching for birds and small mammals, usually practiced in managed habitats.

Specialized hunters also used hunting grounds upriver (Javari, Ituí, Itaquaí, or Curuçá rivers), within indigenous territories where they have no legitimate use of forest resources. They reach those hunting grounds by boat and link their hunting activities with illegal wood extraction, spending from $5 \mathrm{~h}$ to 5 days along the Javari River. Hunting trips to those remote areas are organized in groups (two to six people) when medium-sized and large mammals are the main objective, usually for long periods of time (up to 7 days). Camps are usually built near streams and at a walking distance (15-40 min) from key hunting spots. Once the hunter finishes his hunting trip, he calls his customers by mobile phone to sell the bushmeat as quickly as possible.

\section{Incentives and risks}

Given that urban hunters live close to forest areas and are socially well connected to legitimate users of the hunting grounds (relatives, friends), hunting is an activity that contributes nicely to their livelihoods, either as a direct source of animal protein or a means to obtain money to buy food (chicken, beef, fish, beans, rice, sugar, bread, cassava, salt, coffee, oil, garlic, pepper, pasta), basic products (soap, detergent, school supplies, clothing), hunting supplies (gasoline, matches, cartridges, batteries, lanterns, motorbike or bike parts), fishing supplies (fish hooks, nets), and agricultural equipment (chainsaws, scythes), and make household payments (rent, public services, education). Other incentives reported were: providing healthier food for their families as compared with processed domestic meat; the pleasure of being out of the city and being adventurous, in a healthy and relaxed environment with good food available; the importance of strengthening social links within communities through the habit of sharing bushmeat with family members, friends, and neighbors, especially during family celebrations; and finally, the lack of formal jobs available for illiterate people (which is the case for several hunters interviewed). 
In interviews, hunters stated that there were a certain number of barriers associated with engaging in hunting. Urban hunters report that the main barrier for other men to engage in hunting is the fact that only a few of the urban men have inherited hunting knowledge. Among those that know how to hunt, the main barrier to hunting is legitimate access to hunting grounds. Indeed, for those who are not well linked to hunting grounds through solid social networks, territorial control carried out by indigenous authorities and law enforcement by government institutions represent a high risk for bushmeat and equipment (shotguns, gasoline, motor, boats) confiscations, fines, and even jail time. We found that $73 \%$ of the commercial hunters indentified had already been penalized by environmental and territorial authorities through fines, confiscations, community work, or jail time. Specialized hunters who trade large quantities of bushmeat incur the highest risks. They are pushed to travel at night and early morning using wet cloths over their outboard motors to silent them as a way to avoid being discovered by authorities or indigenous groups along the rivers. A common practice among hunters is to buy hunting supplies (cartridges and shotguns) in the Peruvian town of Islandia, across the river from Benjamin Constant, were surveillance is less intense. However, the best strategy is the use of mobile phones to be informed about bushmeat availability, prices, and controls. Natural hazards such as snake bites and jaguar attacks are reported, as well as the risk of getting lost and accidents when handling shotguns and traps because most of them are handmade and old. Some hunters reported the hazard of being killed by other hunters in the forests as revenge for personal problems such as debts or infidelities.

\section{DISCUSSION}

Urban hunters in the Amazon provide an example of how traditional wildlife use practices adapt to changing contexts rather than disappear. Urbanization and access to markets provide opportunities to diversify incomes through urban jobs, but agricultural and forest-related activities remain part of urban household livelihoods in Amazonian small towns (Stoian 2005). The adaptation of wildlife use practices to urban contexts is possible due to a number of favorable factors: new technologies for transportation (motor bikes, outboard boats) and communication (mobile phones), proximity to hunting grounds, social links with legitimate forest users, and ability to complement livelihoods based on urban jobs and social benefits (Parry et al. 2010). These results highlight the importance of understanding how urbanization patterns determine the continuity of ecosystem services in urban areas through complex interactions and feedback mechanisms linking urban activities and their spatial organization to land cover and environmental change, and raise questions about how to plan urban growth to sustain ecosystem services in urban areas (Alberti 2010).

Our results also provide evidence for the need to redefine subsistence hunting in current legal frameworks, taking into account the realities of the modern Amazon. In the study area, urban hunters hunt for both subsistence and trade. While hunting for commercial purposes is clearly banned under Brazilian law (Pérez and Ojasti 1996), subsistence hunting is allowed in indigenous territories and agro-extractivist reserves. However, current regulatory frameworks do not explicitly mention whether hunting for subsistence by urban hunters is illegal. With Amazonian households being increasingly multi-sited and dynamic (Padoch et al. 2008), noncommercial flows of bushmeat from rural to urban areas, considered as part of households' subsistence, are likely to increase. Currently, urban hunters are faced with risks of penalization (from confiscation to jail time) based on the assumption that they hunt for sale, but our study shows that the subsistence component of their activity is not insignificant, particularly for diversified hunters. Rather, hunting among urban dwellers is multi-functional, as defined by Fischer et al. (2013), and plays a number of different roles: the provision of food and income, but also as a source of pleasure and strengthening of social bonds.

Despite the fact that only a small proportion of urban men hunt $(0.15 \%$ of urban men), our results show that urban hunting exists, and the implications for conservation and local governance should not be disregarded. Some species most commonly hunted by urban hunters are near threatened (some Crypturellus sp. and Crax sp.) or vulnerable (e.g. Tapirus terrestris, Podocnemis unifilis), and the use of automatic traps reduces the selectivity of hunting. Even the hunting of the common Cuniculus paca in Alto Salimoes communities may be unsustainable under current deforestation and hunting pressures (Valsecchi et al. 2014). Specialized hunters, whose main purpose is commercial, usually hunt in remote hunting grounds in territories where they do not necessarily have legitimacy for the use of wildlife, creating conflicts not only with governmental authorities but also with indigenous authorities.

\section{Acknowledgments:}

We acknowledge the active contribution of all hunters that actively participated in this work, always maintaining a great spirit of collaboration and rigorous research principles. This work would not have been possible without support from the University of Sao Paolo, UFAM, and UEA in Brazil. This work was supported by funding from USAID and UKAID through the CGIAR research program on Forests, Trees and Agroforestry and the CIFOR bushmeat research initiative.

\section{LITERATURE CITED}

Adams, C., L. C. Munari, N. van Vliet, R. S. S. Murrieta, B. A. Piperata, C. Futemma, N. N. Pedroso Jr., C. S. Taqueda, M. A. Crevelaro, and V. L. Spressola-Prado. 2013. Diversifying incomes and losing landscape complexity in Quilombo shifting cultivation communities from the Atlantic rainforest (Brazil). Human Ecology 41(1):119-137. http://dx.doi.org/10.1007/s10745-012-9529-9

Albán Morán, E., A. Rabines Flores, M. Suárez Alvites, R. Linares Prieto, and M. Guimaraes Lima. 2004. Manejo sostenible de los recursos agroforestales de las áreas fronterizas amazónicas de Brasil, Colombia y Perú: I fase: volumen I: contenido tematico. Ministerio de Vivienda, Construcción y Saneamiento, Instituto Nacional de Desarrollo, Lima, Peru. [online] URL: http://www. bvcooperacion.pe/biblioteca/bitstream/123456789/485/3/BVCI0000076. pdf.

Alberti, M. 2010. Maintaining ecological integrity and sustaining ecosystem function in urban areas. Current Opinion in 
Environmental Sustainability 2(3):178-184. http://dx.doi.org/10.1016/ j.cosust.2010.07.002

Alexiades, M. N., editor. 2009. Mobility and migration in Indigenous Amazonia: contemporary ethnoecological perspectives. Berghahn Books, New York, New York, USA.

Ayres, J. M., and C. Ayres. 1979. Aspectos de caça no alto rio Aripuaña. Acta Amazónica 9:287-298.

Barlow, J., R. M. Ewers, L. Anderson, L. E. O. C. Aragao, T. R. Baker, E. Boyd, T. R. Feldpausch, E. Gloor, A. Hall, Y. Malhi, W. Milliken, M. Mulligan, L. Parry, T. Pennington, C. A. Peres, O. L. Phillips, R. M. Roman-Cuesta, J. A. Tobias, and T. A. Gardner. 2011. Using learning networks to understand complex systems: a case study of biological, geophysical and social research in the Amazon. Biological Reviews 86(2):457-474. http:// dx.doi.org/10.1111/j.1469-185X.2010.00155.X

Bodmer, R. E., J. F. Eisenberg, and K. H. Redford. 1997. Hunting and the likelihood of extinction of Amazonian mammals. Conservation Biology 11(2):460-466. http://dx.doi.org/10.1046/ j.1523-1739.1997.96022.X

Bodmer, R. E., and E. P. Lozano. 2001. Rural development and sustainable wildlife use in Peru. Conservation Biology 15 (4):1163-1170. http://dx.doi.org/10.1046/j.1523-1739.2001.0150041163. $\underline{\mathrm{x}}$

Bodmer, R. E., E. P. Lozano, and T. G. Fang. 2004. Economic analysis of wildlife use in the Peruvian Amazon. Pages 191-207 in K. M. Silvius, R. Bodmer, and J. M. V. Fragoso, editors. People and nature: wildlife conservation in South and Central America. Columbia University Press, New York, New York, USA.

Bonaudo, T., Y. Le Pendu, J. F. Faure, and D. Quanz. 2005. The effects of deforestation on wildlife along the transamazon highway. European Journal of Wildlife Research 51(3):199-206. http://dx.doi.org/10.1007/s10344-005-0092-1

Brondizio, E. S., E. Ostrom, and O. R. Young. 2009. Connectivity and the governance of multilevel social-ecological systems: the role of social capital. Annual Review of Environment and Resources 34:253-278. http://dx.doi.org/10.1146/annurev.environ.020708.100707

Coelho, M. R., E. C. C. Fidalgo, F. O. Araújo, H. G. Santos, M. L. Mendonça-Santos, D. V. Pérez, and F. M. S. Moreira. 2005. Levantamento pedológico de uma área-piloto relacionada ao projeto BiosBrasil (Conservation and sustainable management of below-ground biodiversity: phase I), municipio de Benjamin Constant ( $A M$ ): janela 6. Boletim de Pesquisa e Desenvolvimento 68. Embrapa, Rio de Janeiro, Brazil. [online] URL: http://ainfo. cnptia.embrapa.br/digital/bitstream/item/89680/1/bpd68-2005-areapiloto-proj-bios-br.pdf.

da Silva, A. I. C. 2009. Govenança ambiental e segurança alimentar: a agricultura familiar no alto solimões, AM. Dissertation. Universidade Federal do Amazonas, Manaus, Brazil. [online] URL: http://livros01.livrosgratis.com.br/cp126318.pdf.

da Silva, M. N. F., G. H. Shepard Jr., and D. W. Yu. 2005. Conservation implications of primate hunting practices among the Matsigenka of Manu National Park. Neotropical Primates 13 (2):31-36. http://dx.doi.org/10.1896/1413-4705.13.2.31

Eloy, L., and F.-M. Le Tourneau. 2009. L'urbanisation provoque- t-elle la déforestation en Amazonie? Innovations territoriales et agricoles dans le nord-ouest Amazonien (Brésil). Annales de Géographie 667(3):204-227. http://dx.doi.org/10.3917/ag.667.0204

Emídio-Silva, C. 1998. A caça de subsistência praticada pelos indios Parakanã (sudeste do Pará): características e sustentabilidade. Thesis. Universidade Federal do Pará and Museu Paraense Emílio Goeldi, Belém, Brazil.

Fischer, A., C. Sandström, M. Delibes-Mateos, B. Arroyo, D. Tadie, D. Randall, F. Hailu, A. Lowassa, M. Msuha, V. Kereži, S. Reljić, J. Linnell, and A. Majic. 2013. On the multifunctionality of hunting - an institutional analysis of eight cases from Europe and Africa. Journal of Environmental Planning and Management 56(4):531-552. http://dx.doi.org/10.1080/09640568.2012.689615

Galvâo, E. 1967. Indigenous culture areas of Brazil (1900-1959). Pages 167-205 in J. H. Hopper, editor. Indians of Brazil in the twentieth century. Institute for Cross Cultural Research, Washington, D.C., USA.

Gasparetto Higuchi, M. I., M. G. Aguilar Calegare, M. L. S. Graciosa Porto, M. B. D. F. Lima, and R. Machado Freitosa. 2011. Diagnóstico socioambiental do municipio de Atalaia do NortelAM. ProjetoCADAF. Laboratório de Psicologia e Educação Ambiental, Manaus, Brazil. [online] URL: http://www. academia.edu/7151865/Diagnostico socioambiental do municipio de Atalaia do Norte AM.

Gavin, M. C. 2007. Foraging in the fallows: hunting patterns across a sucessional continuum in the Peruvian Amazon. Biological Conservation 134(1):64-72. http://dx.doi.org/10.1016/j. biocon.2006.07.011

Hurtado-Gonzales, J. L., and R. E. Bodmer. 2004. Assessing the sustainability of brocket deer hunting in the TamshiyacuTahuayo Communal Reserve, northeastern Peru. Biological Conservation 116(1):1-7. http://dx.doi.org/10.1016/S0006-3207 (03)00167-8

IBGE [Instituto Brasileiro de Geografia e Estatística]. 2000. Censo demográfico 2000: migração e deslocamento: resultados da amostra. IBGE, Rio de Janiero, Brazil. [online] URL: http://www. ibge.gov.br/home/estatistica/populacao/censo2000/migracao/ censo2000_migracao.pdf.

IBGE [Instituto Brasileiro de Geografia e Estatística]. 2013. Estimativas da população residente nos municípios brasileiros com data de referência em $1^{\circ}$ de julho de 2013. IBGE, Rio de Janiero, Brazil. [online] URL: http://www.ibge.gov.br/home/estatistica/ populacao/estimativa2013/estimativa dou.shtm.

Iwamura, T., E. F. Lambin, K. M. Silvius, J. B. Luzar, and J. M. V. Fragoso. 2014. Agent-based modeling of hunting and subsistence agriculture on indigenous lands: understanding interactions between social and ecological systems. Environmental Modelling and Software 58:109-127. http://dx.doi.org/10.1016/j. envsoft.2014.03.008

Levi, T., G. H. Shepard Jr., J. Ohl-Schacherer, C. A. Peres, and D. W. Yu. 2009. Modelling the long term sustainability of indigenous hunting in Manu National Park, Peru: landscape-scale management implications for Amazonia. Journal of Applied Ecology 46(4):804-814. http://dx.doi.org/10.1111/j.1365-2664.2009.01661. $\underline{x}$ 
Lopes, M. A., and S. F. Ferrari. 2000. Effects of human colonization on the abundance and diversity of mammals in eastern Brazilian Amazonia. Conservation Biology 14 (6):1658-1665. http://dx.doi.org/10.1111/j.1523-1739.2000.98402. $\underline{\mathrm{x}}$

Nasi, R., A. Taber, and N. van Vliet. 2011. Empty forests, empty stomachs? Bushmeat and livelihoods in the Congo and Amazon basins. International Forestry Review 13(3):355-368. http://dx.doi. org/10.1505/146554811798293872

Nasuti, S., L. Eloy, C. Raimbert, and F.-M. Le Tourneau. 2013. Can rural-urban household mobility indicate differences in resource management within Amazonian communities? Bulletin of Latin American Research 34(1):35-52. http://dx.doi. org/10.1111/blar.12147

Nepstad, D., S. Schwartzman, B. Bamberger, M. Santilli, D. Ray, P. Schlesinger, P. Lefebvre, A. Alencar, E. Prinz, G. Fiske, and A. Rolla. 2006. Inhibition of Amazon deforestation and fire by parks and indigenous lands. Conservation Biology 20(1):65-73. http:// dx.doi.org/10.1111/j.1523-1739.2006.00351.x

Ojasti, J. 2000. Manejo de fauna neotropical. Instituto de Zoología Tropical, Caracas, Venezuela.

Padoch, C., E. Brondizio, S. Costa, M. Pinedo-Vasquez, R. R. Sears, and A. Siqueira. 2008. Urban forest and rural cities: multisited households, consumption patterns, and forest resources in Amazonia. Ecology and Society 13(2): 2. [online] URL: http:// www.ecologyandsociety.org/vol13/iss2/art2/.

Parry, L., J. Barlow, and C. A. Peres. 2009. Hunting for sustainability in tropical secondary forests. Conservation Biology 23(5):1270-1280. http://dx.doi.org/10.1111/j.1523-1739.2009.01224. $\underline{\mathrm{X}}$

Parry, L., B. Day, S. Amaral, and C. A. Peres. 2010. Drivers of rural exodus from Amazonian headwaters. Population and Environment 32(2-3):137-176. http://dx.doi.org/10.1007/s11111-010-0127-8

Peiter, P. C., V. da Cruz Franco, R. Gracie, D. R. Xavier, and M. C. Suárez-Mutis. 2013. Situação da malária na tríplice fronteira entre Brasil, Colômbia e Peru. Cadernos de Saúde Pública 29 (12):2497-2512. http://dx.doi.org/10.1590/0102-311X00042213

Peres, C. A. 2001. Synergistic effects of subsistence hunting and habitat fragmentation on Amazonian forest vertebrates. Conservation Biology 15(6):1490-1505. http://dx.doi.org/10.1046/ j.1523-1739.2001.01089.x

Pérez, E. M., and J. Ojasti. 1996. La utilización de la fauna silvestre en la América tropical y recomendaciones para su manejo sustentable en las sabanas. Ecotropicos 9(2):71-82. [online] URL: http://www.saber.ula.ve/bitstream/123456789/25731/2/articulo3.pdf.

Prado, H. M., L. C. Forline, and R. Kipnis. 2012. Hunting practices among the Awá-Guajá: towards a long-term analysis of sustainability in an Amazonian indigenous community. Boletim do Museo Paraense Emílio Goeldi: Ciências Humanas 7 (2):479-491. http://dx.doi.org/10.1590/S1981-81222012000200010

Read, J. M., J. M. V. Fragoso, K. M. Silvius, J. Luzar, H. Overman, A. Cummings, S. T. Giery, and L. Flamarion de Oliveira. 2010.
Space, place, and hunting patterns among indigenous peoples of the Guyanese Rupuni region. Journal of Latin American Geography 9(3):213-243. http://dx.doi.org/10.1353/lag.2010.0030

Schwartzman, S., A. Moreira, and D. Nepstad. 2000. Rethinking tropical forest conservation: perils in parks. Conservation Biology 14(5):1351-1357. http://dx.doi.org/10.1046/j.1523-1739.2000.99329. $\underline{\mathrm{X}}$

Serrâo Acioli, A. N., and P. V. Cassiano Oliveira. 2013. Cupins (Isoptera) invasores da rede elétrica em áreas urbanas na Região do Alto Solimões, Amazônia Ocidental, Brasil. EntomoBrasilis 6 (2):150-156. [online] URL: http://www.periodico.ebras.bio.br/ ojs/index.php/ebras/article/view/ebrasilis.v6i2.332/235.

Shepard, G. H. Jr., T. Levi, E. Góes Neves, C. A. Peres, and D. W. Yu. 2012. Hunting in ancient and modern Amazonia: rethinking sustainability. American Anthropologist 114(4):652-667. http://dx.doi.org/10.1111/j.1548-1433.2012.01514.X

Sills, E., P. Shanley, F. Paumgarten, J. de Beer, and A. Pierce. 2011. Evolving perspectives on non-timber forest products. Pages 23-51 in S. Shackelton, C. Shackelton, and P. Shanley, editors. Nontimber forest products in the global context. Springer, Berlin, Germany. http://dx.doi.org/10.1007/978-3-642-17983-9 2

Steward, C. 2007. From colonization to "environmental soy": a case study of environmental and socio-economic valuation in the Amazon soy frontier. Agriculture and Human Values 24 (1):107-122. http://dx.doi.org/10.1007/s10460-006-9030-4

Stoian, D. 2005. Making the best of two worlds: rural and periurban livelihood options sustained by nontimber forest products from the Bolivian Amazon. World Development 33(9):1473-1490. http://dx.doi.org/10.1016/j.worlddev.2004.10.009

Valsecchi, J., H. R. El Bizri, and J. E. C. Figueira. 2014. Susistence hunting of Cuniculus paca in the middle of the Solimões River, Amazonas, Brazil. Brazilian Journal of Biology 74(3):560-568. http://dx.doi.org/10.1590/bjb.2014.0098

Zapata-Ríos, G. 2001. Sustentabilidad de la cacería de subsistencia: el caso de cuatro comunidades quichuas en la Amazonía nororiental ecuatoriana. Journal of Neotropical Mammalogy 8(1):59-66. [online] URL: http://www.sarem.org.ar/ wp-content/uploads/2012/11/SAREM MastNeotrop 8-1 06 ZapataRios. pdf.

Zapata-Ríos, G., C. Urgilés, and E. Suárez. 2009. Mammal hunting by the Shuar of the Ecuadorian Amazon: Is it sustainable? Oryx 43(3):357-385. http://dx.doi.org/10.1017/ S0030605309001914 
Nome do caçador:

Comunidade:

Idade

Ha quanto tempo mora aquí?

Etnia

\section{TÉCNICAS E PRÁCTICAS DE CAÇA}

Quais animais caça?:
$\square \quad$ Veado cinza
$\square$ Veado vermelho
$\square$ Caititú
$\square \quad$ Anta
$\square$ Tatu
$\square$ Tatú canastra
$\square \quad$ Tracajá
$\square \begin{aligned} & \text { Tartaruga do } \\ & \text { amazonas }\end{aligned}$
$\square$ Jacamín
$\square \quad$ Jacaretinga
$\square$ Jacaré
$\square$ Garça
$\square \quad$ Jacu
$\square$ Mutum
$\square$ Inhnambú

$\square \quad$ Queixada

$\square$ Capivara

$\square \quad$ Paca

$\square$ Cutia

$\square \quad$ Quati

$\square$ Preguiça

$\square \quad$ Macaco

$\square$ Ararinhas

$\square \quad$ Outros Quais?:

\section{Cómo captura os animais?}

$\begin{array}{lll}\text { Armadilha } \quad \square \quad & \text { De qué tipo } \\ \text { Quantos cartuchos voce } & \begin{array}{l}\text { Qutiliza (por faena) } \\ \text { Espingarda } \quad \square\end{array}\end{array}$

Número de
armadilhas (por
jornada)
Vai com
cachorros?

Quanto tempo permanece a armadilha

Describa as suas técnicas de caça:
$\square$ Individual
$\square \quad$ Em grupo

Por jornada de caça, Quantos animais captura?:

Quantas veces vai de caça por mes?

Quantas horas investe por jornada de caça?

\section{CUSTOS DE JORNADA DE CAÇA}

Gasolina

Cartuchos

Pilas

Sal

Outros preço por galão preço de caixa preço do par preço por libra preço
Quanto compra por mes? Quanto compra por mes? Quanto compra por mes? Quanto compra por mes? Quanto compra por mes?
Onde compra?

Onde compra?

Onde compra?

Onde compra?

Onde compra?

Ha quanto tempo voce e caçador?

Como voce aprendeu a caçar?

\section{COMPOSIÇÃO DE ANIMAIS E TERRITORIO}

Animais capturados na ultima semana

Onde?

Animais capturados no ultimo mes/tres meses

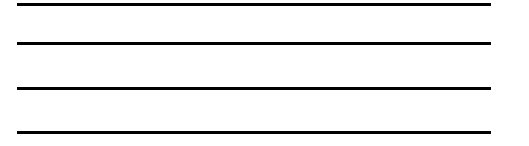


Nome da área de caça preferida:

Tipo de área

$\square \quad$ Floresta fechada

$\square$ Igapó

$\square \quad$ Capoeira

$\square$ Chagra

$\square \quad$ Igarape Outro, qual?

\section{Quantos Canamás voce visita?}

Como voce chega la? (carro, moto, pé):

Quantas horas voce investe para chegar la?

Quem é o dono desse território?:

Como conheceu issas áreas?

$\square \quad$ Por família

$\square$ Amigo

$\square$ Percorriendo

Outro, qual?

Cuándo é mais facil encontrar os animais?
$\square$ Epoca Cheia
Por qué?

$\square$ Epoca Seca

$\square \operatorname{Sim} \quad \square \quad$ Nao

Compartilha com outros os animais que caça?

$\square \operatorname{Sim}$

Com quém?
$\square \quad$ Familia
$\square \quad$ Amigo
$\square \quad$ Chefe

Outra pessoa, qual?

Motivo de caça?

Consumo da família

Pedido do cliente

Quantos clientes voce tem? Quantos clientes sao os mais fiéis?

Caça oportunista

Gosta de caçar

Outra

Qual?

$\square$

Quanto do animal capturado é para: (\%)

Consumo da fa
Venda :
venda da carn
Quilos
Carne fresca
Defumada
Salgada
animal inteiro

uma parte: totalidad $\square$

Qual é a forma de venda da carne?
$\square \quad$ Quilos
$\square \quad$ Carne fresca
$\square$ Defumada
$\square \quad$ Salgada
$\square$ animal inteiro

uma parte: totalidad $\square$ 


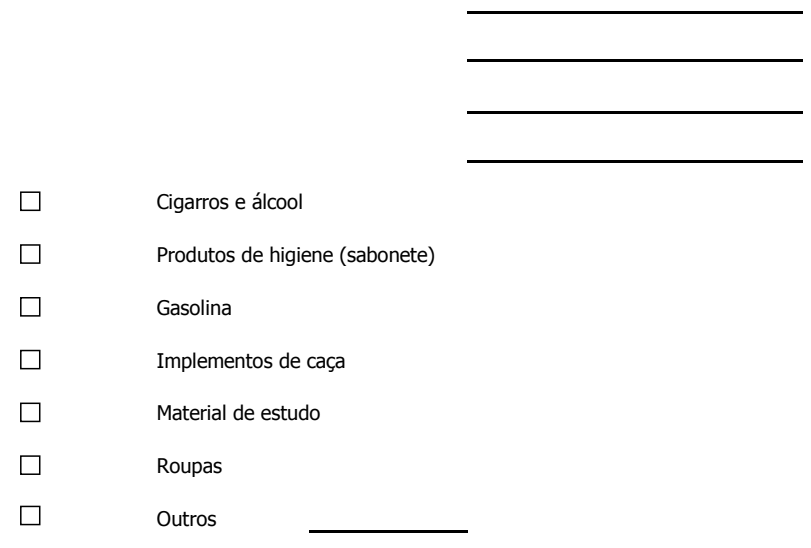

Fiscalização

Tem sido controlado por comerciar carne de caça?

$\square \operatorname{Sim} \quad \square \quad$ Nao

\section{Quem faz a fiscalização? \\ $\square$ Polícia federal}

Tem sido penalizado por comerciar carne de caça?

$\square \quad$ Exercito

Como foi penalizado?

$\square \quad$ Multa

$\square \quad$ Prisão

$\square \operatorname{Sim}$

$\square \quad$ Nao

$\square \quad$ Confisco

$\square \quad$ outro, qual?

\section{OUTRAS ACTIVIDADES PRODUTIVAS}

Que outras actividades produtivas voce faz?

Actividade

Actividade

Voce recebe bolsa para nao cazar?
Quanto vende/trabalha por mes?

Quanto vende/trabalha por mes?

$\square \operatorname{Sim}$

$\square \quad$ Nao

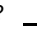

Quanto dinheiro?
Quanto dinheiro ganha por mes? Quanto dinheiro ganha por mes?

\section{CARACTERISTICAS SOCIO-ECONOMICAS}

Lugar onde mora
Casado:
$\square \operatorname{Sim}$
$\square \mathrm{NaO}$
Numero de filhos

Quantos caçadores voce conhece?

Quantas pessoas moran com voce?

\begin{tabular}{|l|l|l|l|l|l|}
\hline Nome & Idade & Parentesco & Sexo & Nivel de educação & Ocupação \\
\hline & & & & & \\
\hline & & & & & \\
\hline & & & & & \\
\hline & & & & & \\
\hline & & & & & \\
\hline
\end{tabular}

Tipo de lar:

$\square$ Basico

$\square \quad$ Medio

$\square$ Luxo

Bienes materiales:

$\square$ Basico

$\square \quad$ Medio

$\square$ Luxo 
